\title{
Pengaruh Pemindahan SUTT 150 kV Celukan Bawang - Kapal Terhadap Aliran Daya Sistem Bali
}

\author{
Muhammad Fauzi $^{1}$, I W. Sukerayasa ${ }^{2}$, W. G. Ariastina ${ }^{3}$
}

\begin{abstract}
To meet the energy needs in Bali Island which is increasing by $6-9 \%$ in the next 5 years, the government has been working on the development of CelukanBawang power plant. The CelukanBawang power plant project completed since 2013 has been fully operational in August 2015 as an outlet for the transmission of $150 \mathrm{kV}$ Over Head Line. Related to the issue of social issues with the keyword of DesaCelukanbawang on the development which is the home for them SUTT, the PT PLN (PERSERO) is asked to implement a strategy for securing the distribution so that the Bali system is safe when the re-route SUTT route. From the simulation result using PSSE Tools, Bali's electric power flow is simulated in 3 scenarios. First scenario is switching off the Circuit 1 of Celukan Bawang - Kapal and Operate the power plants in accordance to their merit orders. Second scenario is switching off the circuit 1 of Celukan Bawang - Kapal and dispatching the southern power plant optimally, and third scenario is switching off both of the circuit 1 and 2 of Celukan Bawang - Kapal and operating the Southern power plant. Based on the results of the analysis of those three scenarios, it can be concluded that first scenario has more economic, reliable and quality than other scenarios.
\end{abstract}

Intisari- Untuk memenuhi kebutuhan energi listrik di Pulau Bali yang semakin meningkat sekitar 6 - $9 \%$ dalam 5 tahun mendatang, pemerintah telah mengupayakan pembangunan PLTU Celukan Bawang. Proyek PLTU Celukan Bawang yang dikerjakan sejak 2013 ini telah beroperasi penuh pada bulan Agustus 2015 sebagai outlet untuk penyaluran transmisi Saluran Udara Tegangan Tinggi (SUTT) 150kV. Terkait masalah isu sosial dengan penolakan warga Desa Celukan bawang terhadap pembangunan yang melintasi rumah mereka dari SUTT, maka pihak PT.PLN (PERSERO) diminta untuk melakukan strategi untuk pengamanan penyaluran agar Sistem Bali aman saat reroute jalur SUTT. Dari hasil simulasi dengan menggunakan Tools PSSE, aliran daya listrik Bali disimulasikan dalam 3 skenario. Skenario 1 melepaskan 1 Sirkit Celukan Bawang Kapal dan mengoperasikan Pembangkit sesuai dengan merit order, skenario 2 melepaskan 1 sirkit Celukan Bawang - Kapal dan mengoptimalkan Pembangkit di Jalur Selatan, dan skenario 3 dilakukan dengan melepas kedua sirkit Celukan Bawang Kapal dan mengoperasikan pembangkit di jalur Selatan. Berdasarkan hasil analisis dari skenario berikut di peroleh skenario 1 memiliki kajian lebih ekonomis, andal dan bermutu dibandingkan skenario lainnya.

Kata Kunci- Analisa Aliran Daya (Load Flow), re-route, PPSE.

${ }^{1}$ Mahasiswa Teknik Elektro Fakultas Teknik Universitas Udayana, Kampus Bukit Jimbaran, Badung Bali.80361, Tel. 0361703315 fax.0361703315; email :oziex.elektrik@gmail.com

${ }^{2,3}$ Dosen Teknik Elektro Fakultas Teknik Universitas Udayana, Kampus Bukit Jimbaran, BadungBali.80361, Tel. 0361703315 fax.0361703315; email :sukerayasa@unud.ac.id, w.ariastina@gmail.com

\section{PENDAHULUAN}

Bali sebagai tujuan wisata Dunia mempunyai pertumbuhan ekonomi yang cukup tinggi yaitu sekitar $6 \%$ per tahun (Sumber: Badan Pusat Statistik Provinsi Bali, 2016), demikian juga permintaan terhadap kebutuhan energi listrik, konsumsi energinya dari tahun 2010-2015 tumbuh sekitar 9\% per tahun[1]. Kecenderungan peningkatan kebutuhan listrik tersebut telah mendorong upaya-upaya peningkatan penyediaan kapasitas pembangkit tenaga listrik maupun perluasan jaringan transmisi dan distribusi agar peningkatan kebutuhan energi listrik dapat terpenuhi.

PT. PLN (Persero) sebagai barometer pelayanan World Class Service (WCS) yang sekarang ditingkatkan menjadi World Class Company (WCC) telah mengupayakan proyek pembangunan Saluran Udara Tegangan Tinggi (SUTT) 150 $\mathrm{kV}$ Celukan Bawang - Kapal yang merupakan outlet Pembangkit Listrik Tenaga Uap (PLTU) Celukan Bawang. Hal ini dilakukan sebagai upaya untuk memenuhi kebutuhan tenaga listrik dan memperluas jariangan transmisi di Bali.

SUTT $150 \mathrm{kV}$ Celukan Bawang-Kapal melintasi perkampungan Barokah, Dusun Pungkukan, Desa Celukan Bawang.Pemasangan kabel Saluran Udara Tegangan Tinggi (SUTT) $150 \mathrm{kV}$ yang melintasi pemukiman warga di Desa Celukan Bawang, Kecamatan Gerokgak, Buleleng, Bali ini berakibat penolakan oleh warga setempat dikarenakan kabel SUTT melintasi rumah warga.Dengan demikian, maka pihak PLN harus mengalihkan penghantar SUTT Celukan BawangKapal dengan menggeser (re-route) tapak tower yang telah berdiri saat ini jauh dari pemukiman warga. Untuk menggeser (re-route) tapak tower dan mendesain ulang penghantar SUTT tersebut terlebih dahulu pihak PT. PLN (Persero) harus melakukan pembebasan tegangan pada kedua sirkit tersebut dan hal ini mengakibatkan penyaluran aliran daya di sisi 150 $\mathrm{kV}$ Sistem Bali berubah.

Penelitian ini akan membahas kondisi pembebanan di Sub Sistem Bali untuk menjaga kontinyuitas aliran daya pada sistem Transmisi $150 \mathrm{kV}$ di Bali dengan menganalisis aliran daya pada keadaan normal, dan kondisi aliran daya saat pembebasan tegangan pada penghantar SUTT Celukan Bawang - Kapal baik 1 (satu) sirkit maupun 2 (dua) sirkit menggunakan aplikasi PSS/E 33.5.

\section{STUDI LITERATUR}

\section{A. Tinjauan Mutakhir}

Berikut ini beberapa contoh penelitian yang sebelumnya sudah pernah ada, berdasarkan tinjauan mutakhir ini penulis mendapatkan bahan referensi untuk menulis jurnal ini.

Penelitian yang berjudul "Studi Rugi Daya Sistem Kelistrikan Bali Akibat Perubahan Kapasitas Pembangkitan di Pesanggaran”. Dalam penelitian tersebut menunjukkan bahwa peningkatan maupun pengurangan kapasitas 
DOI: https://doi.org/10.24843/MITE.2018.v17i01.P12

pembangkit pada sistem kelistrikan Bali akan menimbulkan perubahan-perubahan yang signifikan terhadap aliran daya, rugi daya dan rugi energi pada saluran transmisi sistem kelistrikan Bali[7].

Jurnal yang berjudul "Analisa Aliran Daya Optimal Pada Sistem Kelistrikan Bali". Dalam penelitian ini membahas tentang optimasi yang digunakan adalah metode optimasi aliran daya dengan menggunakan Interior Point Optimal Power Flow (IP OPF) A Primal Dual Algorithms with Barrier Function. Optimasi dilakukan dengan tujuan meminimumkan fungsi biaya pembangkitan (Fuel Cost) dengan tetap memenuhi keseimbangan beban dan tidak melanggar kendala yang ditentukan diantaranya batas atas dan bawah daya aktif, daya reaktif serta tegangan[6].

Jurnal yang berjudul "Analisis Pembebanan Ekonomis pada Jaringan 500 kV Jawa Bali Menggunakan Software PowerWorld". Dalam penelitian ini membahas tentang Economic Dispatch, bahwa dalam keadaan normal, Economic Dispatch dan Optimal Power Flow menggunakan software PowerWorld menghasilkan nilai biaya yang sama. Keadaan normal diartikan tidak terdapat pelanggaran terhadap batas kemampuan saluran transmisi. Namun, pada saat terjadi pelanggaran batas saluran transmisi, hasil pada Economic Dispatch lebih murah dari hasil Optimal Power Flow. Hal ini karena pada Economic Dispatch, batasan saluran transmisi tidak diperhatikan sehingga pembangkit yang termurah bisa dioptimalkan dan daya yang melewati salurandapat lebih besar dari batas kemampuannya[10].

Jurnal yang berjudul "Studi Aliran Daya Pada Sistem Kelistrikan Sumatera Bagian Utara (Sumbagut) $150 \mathrm{kV}$ dengan Menggunakan Software Powerworld Versi 17”. Dalam penelitian tersebut membahas tentang studi aliran daya pada sistem kelistrikan Sumatera Bagian Utara (SUMBAGUT) $150 \mathrm{kV}$ pada kondisi normal saat seluruh pembangkit dan seluruh beban yang ada beroperasi dengan menggunakan Software PowerWorld Simulator versi 17 dengan metode analisisnya menggunakan metode NewtonRhapson. Studi aliran daya dilakukan untuk mengetahui profil tegangan, aliran daya aktif dan daya reaktif serta rugi-rugi jaringan pada masing-masing busbar yang bermanfaat dalam operasional sistem kelistrikan[9].

Ditinjau dari State of The Art diatas, sama - sama meneliti tentang analisis aliran daya pada saluran transmisi. Sedangkan perbedaan penelitian yang saya lakukan adalah Pertama membahas kajian yang terjadi pada saat SUTT 150 KV Celukan Bawang - Kapal saat re-route. Kedua mengunakan tools PSSE 33 (Power System Simulation Engineering) sebagai alat simulasi[2]. Dan ketiga mengevaluasi dan melakukan rekonfigurasi sigle line diagram pada PSSE untuk menjadikan penghantar yang kelebihan beban menjadi aman.

\section{B. Studi Aliran Daya}

Studi aliran daya di dalam sistem tenaga merupakan studi yang penting. Studi aliran daya mengungkapkan kinerja dan aliran daya (nyata dan reaktif) untuk keadaan tertentu tatkala sistem bekerja saat tunak (steady state). Studi aliran daya juga memberikan informasi mengenai beban saluran transmisi di sistem, tegangan di setiap lokasi untuk evaluasi regulasi kinerja sistem tenaga dan bertujuan untuk menentukan besarnya daya nyata (real power), daya reaktif (reactive power) di berbagai titik pada sistem daya yang dalam keadaan berlangsung atau diharapkan untuk operasi normal.

\section{Tujuan Operasi Sistem}

Tujuan operasi sistem tenaga listrik yaitu ekonomi, keandalan dan kualitas seperti terlihat pada gambar 1 di bawah ini.

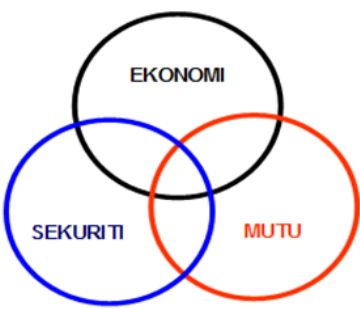

Gambar 1: Tujuan pengendalian operasi sistem tenaga listrik

Dalam operasi sistem tenaga listrik harus memenuhi kriteria tujuan operasi mutu, ekonomis, sekuriti namun kondisi ini sulit untuk dipenuhi sehingga prioritas/urutan bisa berubah tergantung kondisi sistem. Sebagai contoh, dalam kondisi siaga tujuan ekonomi bisa menjadi prioritas terakhir dan yang diutamakan adalah keandalan. Contoh lain dalam kondisi kualitas dan keandalan terpenuhi maka ekonomi menjadi prioritas utama.

\section{Peran Pembangkit Dalam Operasi Sistem}

\section{Pemikul Beban Dasar}

Pembangkit dengan 5000 jam operasi rata-rata per tahun (capacity factor $>57 \%$ ) disebut pembangkit pemikul bebandasar[4]. Pembangkit dalam kategori ini memiliki daya keluaran besar, biaya kapital tinggi dan biaya operasi rendah. Pembangkit tenaga nuklir dan pembangkit tenaga uap berbahan-bakar batubara biasanya digunakan sebagai pemikul beban dasar[4].

Pemikul Beban Menengah

Pembangkit dengan jam operasi lebih besar dari 2000 jam per tahun dan lebih kecil dari 5000 jam rata-rata pertahun $(23 \%>$ capacity factor $>57 \%)$ disebut pembangkit pemikul beban menengah. Pembangkit combined cycled, pembangkit berbahan-bakar minyak dan pembangkit tua yang kurang efisien digunakan untuk pemikul beban menengah[4].

Pemikul Beban Puncak

Pembangkit pemikul beban puncak dioperasikan untuk memenuhi beban pada waktu beban maksimum (beban puncak). Periode bebanpuncak tidak selalu sama. Jam operasi pembangkit ini kurang dari 2000 jam rata-rata per tahun (capacity factor $<23 \%$ ), sehingga pembangkityang dipilih biasanya yang berbiaya kapital rendah. Biaya operasi jenispembangkit ini biasanya tinggi, menyebabkan biaya keseluruhan pembangkitan menjadi tinggi. Pembangkit tenaga

Muhammad Fauzi: Pengaruh Pemindahan SUTT 150 kV ... p p-ISSN:1693 - 2951; e-ISSN: 2503-2372 
(turbin) gas, air, pumped-storage dan mesin Diesel digunakan sebagai pemikul beban puncak[4].

\section{E. Sistem Transmisi Tenaga Listrik}

Saluran transmisi merupakan koridor yang harus dilalui dalam penyaluran energi listrik. Saluran transmisi biasanya dinyatakan menggunakan rangkaian ekivalen[3].

\section{Saluran Udara}

SUTT/SUTET merupakan jenis Saluran Transmisi Tenaga Listrik yang banyak digunakan di PLN daerah Jawa dan Bali karena harganya yang lebih murah dibanding jenis lainnya serta pemeliharaannya mudah.

Pembangunan SUTT/SUTET sudah melalui proses rancang bangun yang aman bagi lingkungan serta sesuai dengan standar keamanan internasional, diantaranya:

- Ketinggian kawat penghantar

- Penampang kawat penghantar

- Daya isolasi

- Medan listrik dan Medan magnet

- Desis corona

\section{Saluran Kabel}

Pada daerah tertentu (umumnya perkotaan) yang mempertimbangkan masalah estetika, lingkungan yang sulit mendapatkan ruang bebas, keandalan yang tinggi, serta jaringan antar pulau, dipasang Saluran Kabel. Jenis - jenis saluran kabel diantaranya adalah:

a. Saluran Kabel Tegangan Tinggi (SKTT) $70 \mathrm{kV}$

b. Saluran Kabel Tegangan Tinggi (SKTT) $150 \mathrm{kV}$

c. Saluran Kabel Laut Tegangan Tinggi (SKLT) $150 \mathrm{kV}$

3. Saluran Gas

Saluran Isolasi Gas (Gas Insulated Line/GIL) adalah Saluran yang diisolasi dengan gas, misalnya: gas SF6. Karena mahal dan resiko terhadap lingkungan sangat tinggi maka saluran ini jarang digunakan.

\section{Interkoneksi Transmisi}

Dengan semakin berkembangnya pusat-pusat pembangkit dan lokasinya yang tersebar maka sistem penyaluran tenaga listrik dibuat saling berhubungan antara satu Subsistem dengan Subsistem lainnya (interkoneksi). Sistem interkoneksi memungkinkan untuk saling memenuhi kebutuhan energi listrik antara satu Subsistem dengan Subsistem lainnya, sehingga defisit energi pada satu Subsistem dapat dihindari selain itu akan memperbaiki stabilitas sistem secara keseluruhan.

Gambar 2 di bawah ini adalah contoh dua subsistem A dan $\mathrm{B}$ yang terinterkoneksi oleh suatu jaringan transmisi.

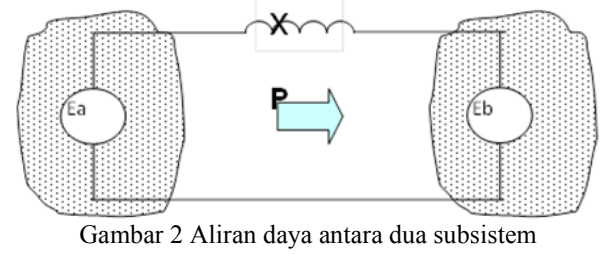

ISSN 1693-2951 Muhammad Fauzi: Pengaruh Pemindahan SUTT 150 kV ...

Arah aliran daya tersebut dapat diubah arahnya dengan melakukan pengaturan tegangan di kedua subsistem tersebut atau dengan cara memaksanya dengan mengubah sudut fase diantara kedua subsistem menggunakan phase sift autotransformer apa salah satu ujung saluran transmisi.

\section{Batas Operasi Transmisi}

Dalam menyalurkan arus listrik,saluran transmisi dibatasi oleh kemampuan hantar arus konduktornya. Kapasitas Hantar Arus Konduktor (KHA) adalah kemampuan konduktor untuk menghantarkan arus. Secara teoretis arus yang dapat mengalir dalam konduktor akan bertambah sampai konduktor mencapai batas temperatur leburnya.

Beberapa faktor yang menentukan KHA konduktor antara lain:

a) Ukuran konduktor, makin besar ukuran penampang konduktor maka makin besar kapasitas arusnya

b) Insulation, panas yang ditimbulkan seharusnya tidak melampaui kemampuan maksimum temperatur insulation

c) Temperatur ambient, makin tinggi temperatur ambient maka lebih sedikit panas yang diperlukan untuk mencapai temperatur maksimum insulation

d) Jumlah konduktor, panas yang didisipasi oleh single konduktor lebih kecil dibanding bundled konduktor

e) Kondisi instalasi, untuk konduktor dalam conduit, duct, trays KHA-nya lebih rendah, hal tersebut dapat diatasi dengan sistem pendinginan yang baik.

\section{Gardu Induk}

a Gardu Induk Transmisi

Gardu induk transmisi merupakan fasilitas dimana saluran transmisi berakhir atau terhubung dengan saluran transmisi lain. Gardu induk transmisi memiliki peralatan untuk memisahkan sistem tenaga dan untuk melepaskan peralatan yang terganggu atau peralatan yang akan dipelihara dari sistem tenaga[5].

Tegangan perlu diturunkan sebelum sampai di konsumen. Oleh sebab itu hampir semua gardu induk transmisi memiliki transformator tenaga untuk menurunkan tegangan transmisi ke tegangan yang lebih rendah.

b Gardu Induk Switching

Gardu induk yang tidak memiliki transformator tenaga disebut gardu induk switching, hanya memiliki peralatan yang diperlukan untuk memisahkan saluran transmisi untuk pemeliharaan peralatan atau untuk mengisolir daerah yang terganggu[5].

\section{Beban}

Dalam menganalisa suatu sistem tenaga listrik, beban tidak diberikan secara lengkap. Untuk merepresentasikan suatu beban dari suatu sistem tenaga listrik, sangat penting untuk mengetahui variasi daya aktif (P) dan daya reaktif (Q) terhadap variasi tegangannya[5].

Di dalam menganalisa suatu sistem tenaga listrik, terdapat 3 cara untuk merepresentasikan suatu beban, antara lain:

a. Representasi beban dengan daya tetap.Dalam hal ini daya aktif P (MW), maupun daya reaktif Q (MVAR) dianggap 
konstan.Representasi beban ini digunakan untuk merepresentasikan beban untuk studi aliran daya.

b. Representasi beban dengan arus tetap. Dalam hal ini arus dihitung sebagai;

$I=\frac{s-j Q}{v *}=I \angle(\theta-\varphi)$

Dimana: $\mathrm{V}=\mathrm{V} \angle \theta$, dan $\varphi=\tan ^{-1} \frac{Q}{P}=$ sudut daya (power factor angle).

c. Representasi beban dengan impedansi tetap.Untuk merepresentasikan suatu beban dengan impedansi tetap, daya yang diserap oleh beban dikonversikan ke dalam bentuk impedansi seri atau parallel. Representasi beban dengan impedansi tetap ini biasanya digunakan pada studi stabilitas suatu sistem tenaga listrik

\section{METODE PENELITIAN}

Dalam analisis aliran daya sistem kelistrikan Bali pada tahun 2016, kondisi beban puncak sistem Bali yang disimulasikan akan disesuaikan dengan Rencana Operasi Tahunan (ROT) 2016. Menurut ROT 2016, beban puncak sistem Bali sebesar $912 \mathrm{MW}$.

Simulasi aliran daya akan dilakukan beberapa tahapan antara lain:

1. Mengumpulkan data dari sumber - sumber yang diperlukan seperti rencana beban puncak sesuai ROT sistem tenaga listrik Jawa Bali 2016, single line diagram eksisting Sub Sistem Bali, data penghantar $150 \mathrm{kV}$ Sub Sistem Bali, data kapasitas transformator distribusi, dan data beban transformator, serta data kondisi daya mampu pembangkit di Sub Sistem Bali.

2. Membuat pemodelan aliran daya sub sistem Bali terlebih dahulu dengan mebuat single line diagram dan jaringan data.
3. Melakukan simulasi aliran daya pada saat kondisi normal menggunakan aplikasi PSS/E[8].

4. Melakukan simulasi sekenario 1 (satu) yaitu dengan melepaskan satu sirkit penghantar SUTT $150 \mathrm{kV}$ Celukan Bawang - Kapal, kemudian mengevaluasi aliran daya yang terjadi saat itu.

5. Melakukan simulasi sekenario 2 (dua) yaitu dengan melepaskan dua sirkit penghantar SUTT $150 \mathrm{kV}$ Celukan Bawang - Kapal, kemudian mengevaluasi aliran daya yang terjadi saat itu serta melakukan rekonfigurasi aliran daya dari kondisi kritikal (pembebanan di atas 80\%) menjadi kondisi aman (pembebanan di bawah $80 \%$ ).

6. Membandingkan hasil analisis dari simulasi kondisi aliran daya normal dengan 2 (dua) sekenario yang direncanakan.

7. Menyimpulkan hasil analisis dan memberikan saran yang bersifat membangun.

\section{PEMBAHASAN}

\section{A. Profil Sistem Kelistrikan $150 \mathrm{kV}$ Bali}

Sistem tenaga listrik $150 \mathrm{kV}$ di Bali mempunyai jaringan transmisi yang terbentang sepanjang 973.5 kilo meter sirkit (kms) terdiri dari 36 saluran dengan 14 Gardu Induk Konvensional dan 2 Gardu Induk Switching[1]. Pada April 2015 telah dioperasikan sebuah Gardu Induk GIS Celukan Bawang yang merupakan outlet dari PLTU Celukan Bawang. Bentuk saluran yang digunakan pada jaringan transmisi 150 $\mathrm{kV}$ di Bali terdiri dari dua jenis yaitu berupa saluran ganda (double circuit) dan saluran tunggal (single circuit). Single line diagram jaringan transmisi $150 \mathrm{kV}$ di Bali ditunjukkan pada gambar 3 di bawah ini.

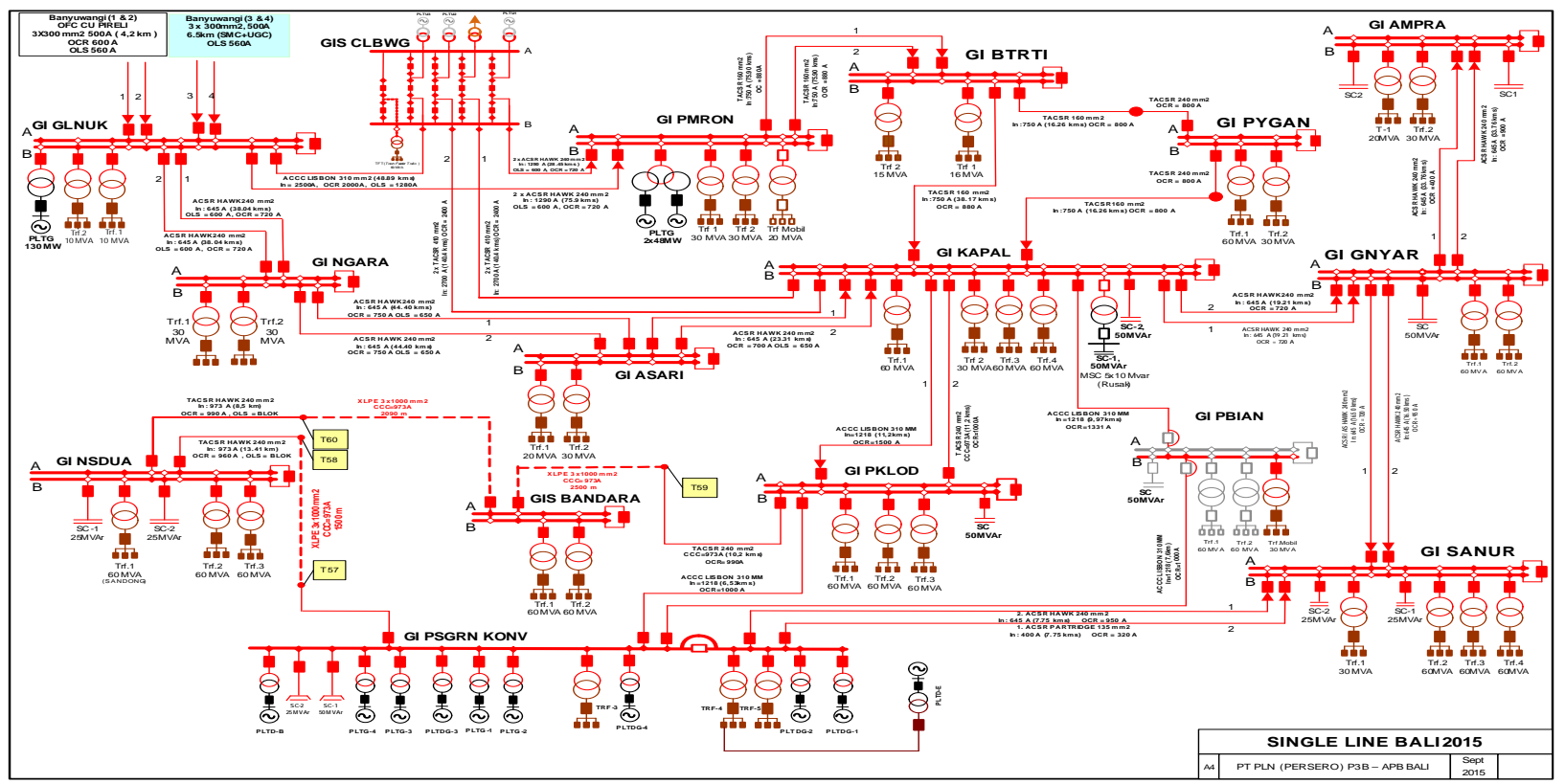

Muhammad Fauzi: Pengaruh Pemindahan SUTT 150 kV ... p p-ISSN:1693 - 2951; e-ISSN: 2503-2372 
Gambar 3 Single line diagram jaringan transmisi $150 \mathrm{kv}$ bali

B. Prediksi Beban Puncak

Dalam analisis aliran daya sistem kelistrikan Bali pada tahun 2016, kondisi beban puncak sistem Bali yang disimulasikan akan disesuaikan dengan Rencana Operasi Tahunan (ROT) 2016. Menurut ROT 2016, beban puncak sistem Bali sebesar $912 \mathrm{MW}$.

C. Evaluasi Analisis Aliran Daya Sistem Bali Saat Pekerjaan Re-Routing

Skenario untuk kajian aliran daya sistem kelistrikan Bali saat re-routing berlangsung akan disimulasikan dalam 3 (tiga) skenario, yaitu:

1. Skenario 1 : SUTT Celukan Bawang - Kapal dilepas 1 sirkit (kondisi pembangkit sesuai merit order)

2. Skenario 2 : SUTT Celukan Bawang - Kapal dilepas 1 sirkit (optimalisasi KIT Selatan)

3. Skenario 3 : SUTT Celukan Bawang - Kapal dilepas 2 sirkit

Re-route Celukan Bawang - Kapal ini harus dilakukan tanpa mengganggu kontinyuitas pelayanan konsumen listrik. Untuk itu perlu adanya kajian resiko dengan mempertimbangkan 3 (tiga) aspek tujuan operasi sistem yang diantaranya ekonomis, andal dan bermutu.

Berikut ini perbandingan pembebanan pembangkit saat rerouting berlangsung antara skenario 1 , skenario 2 dan skenario 3 dapat dilihat pada gambar 4 di bawah.

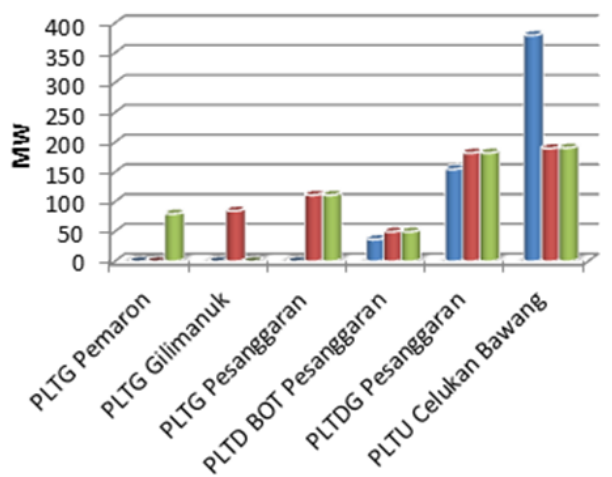

- Skenario 1

= Skenario 2

= Skenario 3

Gambar 4 Perbandingan komposisi pembangkit

Bila ditinjau dari segi komposisi pembebanan pembangkit, maka skenario 1 lebih menguntungkan karena lebih efisien dibandingkan skenario 2 dan skenario 3. Untuk komposisi SKLT dapat dilihat pada gambar no. 5.

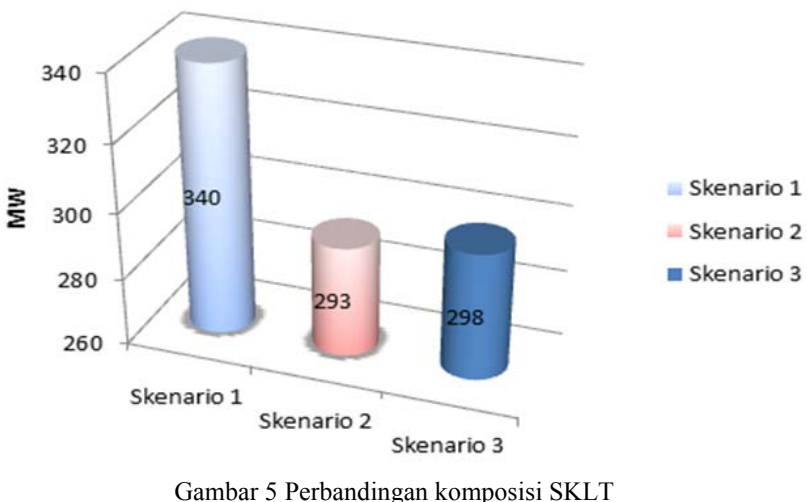

Dikaji dari segi biaya energi yang digunakan pembangkit antara skenario 1 dan 2 dan 3 maka dapat dilihat perbandingannya pada gambar 6 di bawah.

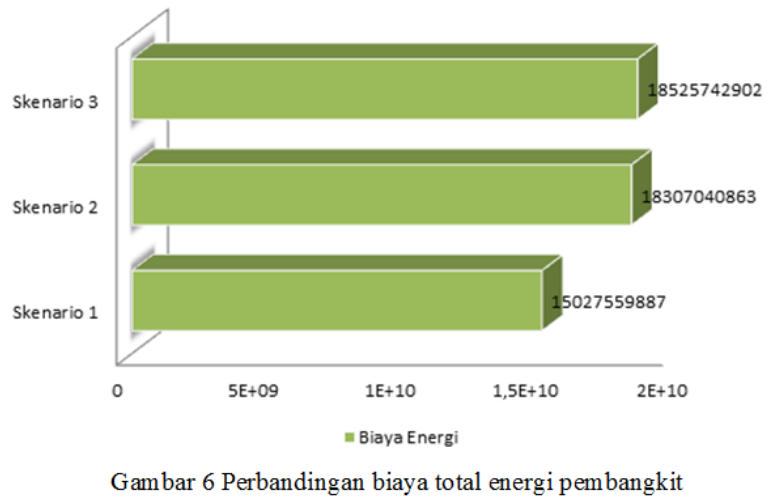

Selanjutnya akan dikaji dari segi keandalan sistem, dalam hal ini akan ada pebandingan besar pembebanan masing masing sirkit $150 \mathrm{kV}$ antara skenario 1, 2 dan 3. Untuk perbandingan loadingnya dapat dilihat pada tabel I di bawah. 


\begin{tabular}{|c|c|c|c|c|c|c|}
\hline \multirow[b]{2}{*}{ NO. } & \multirow[b]{2}{*}{ FROM BUS } & \multirow[b]{2}{*}{ TO BUS } & \multirow[b]{2}{*}{ SIRKIT } & \multicolumn{3}{|c|}{ LOADING (\%) } \\
\hline & & & & $\begin{array}{c}\text { Skenario } \\
1\end{array}$ & $\begin{array}{c}\text { Skenario } \\
2\end{array}$ & $\begin{array}{c}\text { Skenario } \\
3\end{array}$ \\
\hline 1 & BANYUWANGI & GILIMANUK & 1 & 67.1 & 55.6 & 56.5 \\
\hline 2 & BANYUWANGI & GILIMANUK & 2 & 67.1 & 55.6 & 56.5 \\
\hline 3 & BANYUWANGI & GILIMANUK & 3 & 64.3 & 53.2 & 54 \\
\hline 4 & BANYUWANGI & GILIMANUK & 4 & 78.1 & 64.8 & 65.7 \\
\hline 5 & GILIMANUK & NEGARA & 1 & 76.6 & 70 & 87.4 \\
\hline 6 & GILIMANUK & NEGARA & 2 & 76.6 & 70 & 87.4 \\
\hline 7 & GILIMANUK & CELUKAN BAWANG & 1 & 9.2 & 13.1 & 2.4 \\
\hline 8 & NEGARA & ANTOSARI & 1 & 69.4 & 62.9 & 80.4 \\
\hline 9 & NEGARA & ANTOSARI & 2 & 69.4 & 62.9 & 80.4 \\
\hline 10 & ANTOSARI & KAPAL & 1 & 64 & 57.5 & 75 \\
\hline 11 & ANTOSARI & KAPAL & 2 & 64 & 57.5 & 75 \\
\hline 12 & KAPAL & BATURITI & 1 & 35.7 & 24.3 & 63.9 \\
\hline 13 & KAPAL & PAYANGAN & 1 & 25.8 & 16.1 & 52.3 \\
\hline 14 & KAPAL & CELUKAN BAWANG & 1 & - & - & - \\
\hline 15 & KAPAL & CELUKAN BAWANG & 2 & 42.6 & 28.2 & - \\
\hline 16 & PEMARON & BATURITI & 1 & 41.8 & 30.3 & 69.1 \\
\hline 17 & PEMARON & BATURITI & 2 & 41.8 & 30.3 & 69.1 \\
\hline 18 & PEMARON & CELUKAN BAWANG & 1 & 48.6 & 29.5 & 68.3 \\
\hline
\end{tabular}

Di tinjau dari persentase pembebanan disetiap sirkit, ketiga skenario dalam batas aman, hanya saja untuk skenario 3 masih ada sirkit yang pembebanannya melampaui $80 \%$ namun masih dalam kategori aman karena untuk jalur tersebut tediri dari 2 sirkit.

Untuk perbandingan losses pada skenario 1, skenario 2 dan skenario 3 dapat dilihat pada gambar 7 di bawah
Bila ditinjau dari segi biaya Operasi Pembangkit, maka skenario 1 lebih ekonomis, namun bila ditinjau dari segi losses, maka skenario 2 lebih efisien. Oleh karena itu, maka dari kedua skenario ini maka perlu dipertimbangkan kembali untuk menghitung rupiah losses. Untuk itu dapat dilihat pada Tabel II di bawah ini.

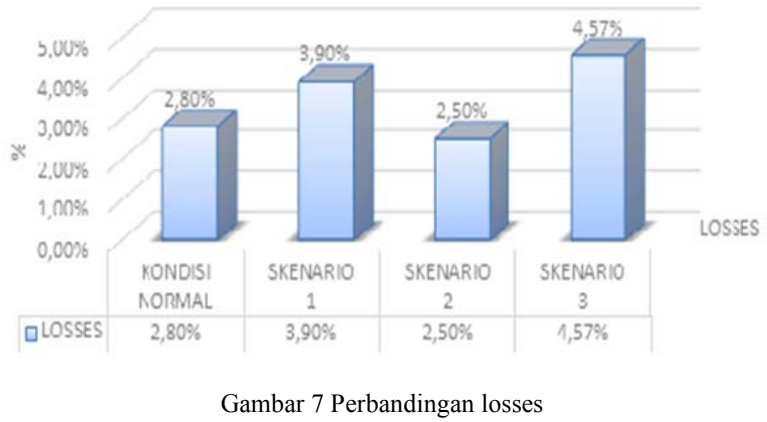

Muhammad Fauzi: Pengaruh Pemindahan SUTT 150 kV ... p-ISSN:1693 - 2951; e-ISSN: 2503-2372 
ABEL II PERHITUNGAN RUPIAH LOSSES

\begin{tabular}{|c|c|c|c|}
\hline SKENARIO & $\mathbf{1}$ & $\mathbf{2}$ & $\mathbf{3}$ \\
\hline KIT (kwh) & 18115650 & 18024263 & 18020562 \\
\hline Biaya KIT (Rp) & 15027559887 & 18307040863 & 18525742902 \\
\hline Rp/kwh & 829.53 & 1015.69 & 1028.03 \\
\hline Losses (MW) & 36.2 & 23.3 & 41.7 \\
\hline Losses (kwh) & 868800 & 559200 & 1000800 \\
\hline $\begin{array}{c}\text { Liaya KIT + } \\
\text { Losses(Rp) }\end{array}$ & 15748259615 & 18875014011 & $\mathbf{1 0 2 8 8 5 5 9 9 0}$ \\
\hline
\end{tabular}

Dilihat pada tabel di atas pada skenario 1 biaya losses Rp 720.699.728,1 dan untuk skenario 2 biaya losses sebesar Rp 567.973.148,- dan setelah ditotal dengan biaya pembangkitan maka didapatkan Biaya akhirnya untuk skenario 1 sebesar Rp 15.748.259.615,- dan skenario 2 sebesar Rp 18.875.014.011,ada penghematan biaya sebesar Rp 3.126.754.395,- untuk skenario 1 terhadap skenario 2 .

Dari segi mutu tegangan akan mempengaruhi kualitas sistem Bali. Berikut ini perbandingan mutu tegangan antara skenario 1, skenario 2 dan skenario 3 dapat dilihat pada gambar 8 di bawah.

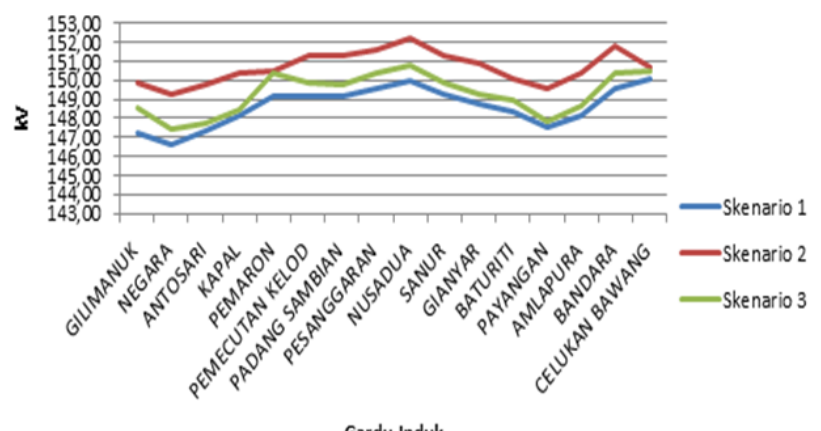

Gambar 8 Perbandingan tegangan setiap gardu induk

Ditinjau dari mutu tegangannya ketiga skenario memiliki kualitas tegangan yang sesuai standarisasi yang diizinkan yaitu $+5 \%$ dari $150 \mathrm{kV}$ dan $-10 \%$ dari $150 \mathrm{kV}$. Mutu tegangan untuk skenario 1 lebih kecil dibandingkan skenario 2 dan skenario 3 namun untuk mengantisipasi turunnya tegangan yang lebih signifikan dapat mengandalkan pengoperasian kapasitor bank $150 \mathrm{kV}$ di salah satu GI yang terdapat fasilitas kapasitor.

Dari hasil kajian dan evaluasi didapat hasil dari perbandingan antara skenario 1, skenario 2, dan skenario 3 diantaranya :

1. Ditinjau dari aspek ekonomis, skenario 1 lebih efisien dibandingkan skenario 2 dan skenario 3,

2. Ditinjau dari aspek kualitas, ketiga skenario ini memiliki tegangan yang memenuhi standarisasi PLN (+5\% dari 150 $\mathrm{kV}$ dan $-10 \%$ dari $150 \mathrm{kV}$ ),

3. Ditinjau dari besarnya pembebanan pada masing-masing sirkit, skenario 2 lebih andal karena pembebanan rataratanya lebih kecil dan lebih aman dibandingkan skenario 1 dan 3 .

\section{KESIMPULAN}

Berdasarkan analisis data dan pembahasan yang telah dilakukan, maka dapat diambil kesimpulan yaitu, untuk sekenario 1 dengan rencana pekerjaan pelepasan SUTT Celukan Bawang-Kapal 1 sirkit menggunakan strategi pengoperasian pembangkit sesuai merit order ini lebih efisien karena dapat menghemat biaya sebesar Rp 3.126.754.395.

\section{REFERENSI}

[1] PLN (Persero). PT. 2016 "Rencana Operasi Sisetem Tenaga Listrik Jawa Bali Tahun 2016" Jakarta Selatan: Pt. PLN (Persero) Pusat Pengatur Beban.

[2] Siemens Industry, Inc. All rights reserved. 2014 "PSS®E-33 Advanced Power Flow".Jerman : Siemens.

[3] Sudirham, Sudaryatno. 2012. "Analisa Sistem Tenaga”. Bandung: Darpublik.

[4] Marsudi, D. 2006. "Pembangkitan Energi Listrik". Jakarta: PT. Erlangga.

[5] Marsudi, D. 2006. "Operasi Sistem Tenaga Listrik". Jakarta: Balai Penerbit \& Humas ISTN

ISSN 1693-2951 Muhammad Fauzi: Pengaruh Pemindahan SUTT 150 kV ... 
Majalah Ilmiah Teknologi Elektro, Vol. 17, No. 1,Januari -April 2018

DOI: https://doi.org/10.24843/MITE.2018.v17i01.P12

[6] Meilandari, E.D, Hartati, R.S, Sukerayasa, I.W. 2012. "Analisa Aliran daya Optimal Pada Sistem Kelistrikan Bali” (Jurnal vol.11 No.1).Denpasar: Universitas Udayana.

[7] Pramana, A.E. 2015. "Studi Rugi Daya Sistem Kelistrikan Bali Akibat Perubahan Kapasitas Pembangkitan di Pesanggaran” (Tugas Akhir). Denpasar: Universitas Udayana.

[8] Angga, M., Furqon, M. 2013. "Panduan Simulasi Aliran Daya dengan PSS/E 31" Denpasar: PT. PLN (Persero) P3B Jawa Bali
93

[9] Lidya, A. 2015 "Studi Aliran Daya Pada Sistem Kelistrikan Sumatera Bagian Utara (Sumbagut) $150 \mathrm{kV}$ dengan Menggunakan Software Powerworld Versi 17" (VOL.11 NO.30/MEI 2015) Medan : Universitas Sumatera Utara.

[10] Badru, T. 2012 “Analisis Pembebanan Ekonomis pada Jaringan $500 \mathrm{kV}$ Jawa Bali Menggunakan Software PowerWorld" (JURNAL TEKNIK ITS Vol. 1, No. 1 (Sept. 2012) ISSN: 2301-9271) Surabaya : Institut Teknologi Sepuluh Nopember.

Muhammad Fauzi: Pengaruh Pemindahan SUTT 150 kV ... p p-ISSN:1693 - 2951; e-ISSN: 2503-2372 